\title{
Soil algae as an indicator of winter wheat integrated cultivation system
}

\section{Glony glebowe jako wskaźnik integrowanej uprawy pszenicy ozimej}

\author{
Dorota Sieminiak
}

\section{Summary}

The studies were carried out in Osiny, the Research Station of the Institute of Soil Science and Plant Cultivation of the State Research Institute in Pulawy. The biomass of soil algae was evaluated in three systems of winter wheat cultivation: organic, conventional and integrated. The goal of the studies was to identify the reaction of soil algae to an implementation of the integrated winter wheat cultivation system. Despite the usage of higher doses of mineral fertilizers in conventional wheat cultivation system than in other systems, the highest algal biomass was recorded in the integrated system. The main reason of the decrease of algal biomass in the conventional system was a second application of a herbicide Chwastox $D$ in spring. Based on the results of the studies of the formation of algal biomass in the soil in integrated system of wheat cultivation and evaluation of the integrated production (IP), it can be stated that soil algae indicate advantages of an application of the integrated system for people's health.

Key words: soil algae; integrated system; winter wheat

\section{Streszczenie}

Badania prowadzono w Osinach, na polach Stacji Doświadczalnej Instytutu Uprawy Nawożenia i Gleboznawstwa - Państwowego Instytutu Badawczego w Puławach. Ocenie podlegała biomasa glonów glebowych w trzech systemach uprawy pszenicy ozimej: ekologicznym, konwencjonalnym i integrowanym. Celem badań było rozpoznanie reakcji glonów glebowych na zastosowanie integrowanego sposobu uprawy pszenicy ozimej. Mimo stosowania wyższych dawek nawozów mineralnych w systemie konwencjonalnym niż $w$ innych systemach, najwyższe wartości biomasy glonów glebowych stwierdzone zostały w systemie integrowanym. Główną przyczyną obniżenia ilości biomasy w systemach konwencjonalnych było stosowanie wiosną drugiego opryskiwania herbicydem Chwastox D. Wobec uzyskanych wyników o kształtowaniu się rozmiarów biomasy glonów w glebie integrowanego systemu uprawy pszenicy i ocen produkcji integrowanej (IP) można stwierdzić, że glony glebowe wskazują na korzyści wypływające ze stosowania integrowanego systemu uprawy dla zdrowia człowieka.

Słowa kluczowe: glony glebowe; system integrowany; pszenica ozima

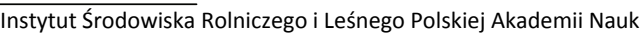

Zakład Systemów Rolniczych

Szeherezady 74, 60-195 Poznań

dsieminiak@poczta.onet.pl 


\section{Wstęp / Introduction}

Glony glebowe są w większości autotrofami. Mają one zdolność wykorzystywania promieniowania słonecznego jako źródła energii i produkowania wszystkich swoich niezbędnych komponentów organicznych $\mathrm{z}$ ich nieorganicznych prekursorów (Sztina i Gollerbach 1969). Stopień uzależnienia glonów od egzogennej materii organicznej wymaga jeszcze badań. Jednakże od początku 20. wieku wiadomo, że wiele glonów jest fakultatywnymi fotoheterotrofami lub chemoheterotrofami (Treubox 1905). I chociaż niektóre glony są nawet fotoauksotrofami, które nie są zdolne do syntetyzowania wszystkich niezbędnych im komponentów organicznych, już przed połową 20. wieku wiadomo było, że rozwój glonów glebowych najczęściej stymuluje obecność fosforu i azotu (Stokes 1940). Wiązanie nadwyżek substancji mineralnych w glebie przez glony wykazano w latach pięćdziesiątych 20. wieku (Fuller i Roger 1952). W dalszym etapie badań odkryto, że glony są producentami materii organicznej najłatwiej uwalniającej substancje mineralne, niezbędne dla rozwoju roślin (Gollerbach i Sztina 1969). Równocześnie zainteresowano się glonami glebowymi jako czułymi wskaźnikami w środowisku. Zasugerowano używanie testów glonowych jako alternatywnych do analiz chemicznych w celu mierzenia ilości zarówno pierwiastków biogennych, jak i toksyn, takich jak pestycydy i inne zanieczyszczenia w glebie (Pipe i Schubert 1984). Wstępna ocena glonów jako wskaźników zanieczyszczenia gleby została przedstawiona przez Sztinę (1990). Wprowadzenie ocen biomasy glonów glebowych w zależności od zmianowania udokumentowało różnice w biomasie glonów w uprawach żyta (żyto po owsie i żyto po życie). Glony tworzyły większą biomasę w uprawach żyta przy zastosowaniu kilkuletniego następstwa roślin (Sieminiak 1998). O możliwości pełnienia roli wskaźnika ekologicznego przez biomasę glonów w uprawach roślin świadczy wynik kolejnych badań prowadzonych w dwóch systemach uprawy ziemniaka: ekologicznym i integrowanym (Sieminiak 2003). Większa biomasa glonów rozwijała się w uprawie integrowanej.

W Polsce integrowana produkcja (IP) uważana jest za nowoczesny system jakości żywności i od 27 listopada 2012 r. regulowana jest przepisami ustawy o ochronie roślin z dnia 18 grudnia 2003 r. (Dz. U. z 2008 r. Nr 133, poz. 849). Stosowanie wydanych przepisów gwarantuje, że w wytworzonych płodach rolnych nie zostały przekroczone dopuszczalne poziomy pozostałości: środków ochrony roślin, metali ciężkich, azotanów, niektórych pierwiastków oraz innych substancji szkodliwych. Ocena biomasy glonów glebowych w uprawach roślin może wskazywać system uprawy korzystniejszy dla zdrowia człowieka. W warunkach zmian struktury zasiewów roślin uprawnych, kiedy stosuje się uproszczenia uprawowe i różne systemy uprawy, ocena biomasy glonów glebowych staje się wyjątkowo przydatna.

Celem badań było rozpoznanie reakcji glonów na zastosowanie integrowanego sposobu uprawy pszenicy ozimej.

\section{Materiały i metody / Materials and methods}

Badania prowadzono na polach Stacji Doświadczalnej w Osinach, należącej do Instytutu Uprawy Nawożenia i Gleboznawstwa - Państwowego Instytutu Badawczego w Puławach, w latach 2001-2002. Gleby pod badanymi uprawami powstały na piaskach gliniastych mocnych i lekkich. Określane są jako bardzo dobry kompleks żytni i dobry kompleks pszenny oraz zaliczane są do gleb płowych (grey-brown podsolic soil).

Przez okres dwóch lat, badaniami objęto trzy systemy uprawy pszenicy: ekologiczny, konwencjonalny (wysokonakładowy) i integrowany (niskonakładowy). W pierwszym roku badań, próby pobierano trzy razy: wiosną, latem i jesienią, w drugim roku, tylko dwa razy, w okresie wegetacji pszenicy. Stosowane zabiegi agrotechniczne zostały przedstawione w tabeli 1. i 2. Przyjęta przez Zakład Systemów i Ekonomiki Produkcji Roślinnej Instytutu Uprawy Nawożenia i Gleboznawstawa - Państwowego Instytutu Badawczego (ZSiEPR IUNG - PIB) norma dawkowania azotu $\mathrm{w}$ ich wieloletnim doświadczeniu wynosiła $144 \mathrm{~kg} / \mathrm{ha}$ azotu mineralnego w systemie integrowanym i $171 \mathrm{~kg} / \mathrm{ha} \mathrm{w}$ konwencjonalnym. Dostarczana ilość azotu była jednak regulowana według aktualnego zapotrzebowania i podczas przedstawianych badań dawki azotu były niższe. W wymienionych systemach produkcji wynosiły kolejno $145 \mathrm{i} 153 \mathrm{~kg} / \mathrm{ha}$ w pierwszym roku badań oraz 135 i $149 \mathrm{~kg} / \mathrm{ha}$ w drugim roku badań. Pola w systemie ekologicznym nie były nawożone azotem mineralnym. W drugim roku badań gleba zasilona została magnezem, siarką i potasem. Poza tym stosowane było nawożenie organiczne - kompost lub obornik w ilości około 30 t/ha pod ziemniaki. Również kontroli zakładu prowadzącego doświadczenie (ZSiEPR IUNG - PIB) podlegało stosowanie herbicydów i fungicydów (tab. 1, 2). Chociaż jako normę przyjęto stosowanie dwóch herbicydów (jeden jesienią, drugi wiosną) w systemie konwencjonalnym i tylko jeden herbicyd (jesienią) w systemie integrowanym, w drugim roku badań oceniono, że nie ma potrzeby zastosowania wiosną drugiego herbicydu w uprawie konwencjonalnej. Fungicydy w drugim roku badań stosowane były zgodnie z założeniem: dwa razy w systemie integrowanym i trzy razy w systemie konwencjonalnym. W pierwszym roku badań liczba ich została zwiększona do trzech $\mathrm{w}$ systemie integrowanym $\mathrm{i}$ do pięciu w systemie konwencjonalnym (tab. 1, 2). Dokładny opis założonego doświadczenia znajduje się w pracach Kusia (1998, 2005) i Jończyka (2005). Dane agrotechniczne i klimatyczne zostały uzyskane z ZSiEPR IUNG - PIB.

Pole zasiane pszenicą w systemie ekologicznym miało prawdopodobnie nieco wyższy niż pozostałe pola poziom wód gruntowych, przez co gleba była tam, w pierwszym roku badań, bardziej wilgotna, a nawet okresowo zalewana, natomiast $\mathrm{w}$ drugim roku przy wyższych temperaturach przesychała. Lata objęte badaniami cechowały odmienne warunki meteorologiczne. Pierwszy rok był chłodniejszy i bardziej wilgotny. W okresie wegetacyjnym opady były wyższe (o $260 \mathrm{~mm}$ wyższa suma opadów) i niższe temperatury (suma temperatur niższa o $298^{\circ} \mathrm{C}$ ). Szczegółowe dane meteorologiczne przedstawia tabela 3. 
Doświadczenie prowadzone było na polach, z których każde miało wielkość około 1 ha i reprezentowało inny system gospodarowania. Pola podzielone były dodatkowo na trzy części po około $330 \mathrm{~m}^{2}$. Próby pobierane były w trzykrotnym powtórzeniu (na trzech poletkach o powierzchni $330 \mathrm{~m}^{2}$ w każdym systemie upraw). Przy każdym powtórzeniu zbierano losowo po 15 prób, wzdłuż transektu przez poletko. Próby pobierane były laską glebową $\mathrm{w}$ warstwie ornej, osobno $\mathrm{z}$ głębokości $0-10$, 10-20 i 20-30 cm. Jednocześnie, przy pomocy łyżeczki, stosując podobne kryteria, pobierane były próby $\mathrm{z}$ powierzchni gleby $(0-0,2 \mathrm{~cm})$.

Biomasa glonów oceniana była na podstawie absorbancji chlorofilu $a$, mierzonej metodą Lorenzena, rekomendowaną do oceny biomasy glonów glebowych (Thomas i wsp. 1981; Sieminiak 1996), przy użyciu UV/Vis Spektrofotometru JASCO V-550.

Zebrane wyniki z warstw gleby 0-10, 10-20 i 20-30 cm zostały zsumowane i przedstawione jako warstwa gleby $0-30 \mathrm{~cm}$. Osobno zanalizowane zostały wyniki z powierzchni gleby, gdzie dostęp światła i stosowanych zabiegów agrotechnicznych (opryskiwania) był największy. Ocenę różnic w ilości glonów rozwijających się w glebie wybranych systemów uprawy pszenicy ozimej przeprowadzono na podstawie analiz średnich wartości biomasy glonów w poszczególnych sezonach każdego roku badań.

Ocenę istotności różnic wyników przeprowadzono przy pomocy analizy wariancji $\mathrm{z}$ zastosowaniem testu NIR $(0,05),(0,01),(0,001)$.

\section{Wyniki i dyskusja / Results and discussion}

Wilgotna i chłodna wiosna (od marca do końca maja) w pierwszym roku badań (opady o $83 \mathrm{~mm}$ wyższe niż $\mathrm{w}$ roku następnym), $\mathrm{z}$ sumą temperatur niższą od następnego roku o około $142^{\circ} \mathrm{C}$, sprzyjała rozwojowi glonów glebowych. Jest to szczególnie widoczne w systemie upraw integrowanych, gdzie średnio biomasa glonów na powierzchni gleby wytworzyła największą masę w okresie badań (rys. 1). Również duża biomasa glonów rozwijała się w warstwie gleby do głębokości $30 \mathrm{~cm}$, trochę mniejsza w systemie upraw ekologicznych (rys. 2). Na powierzchni gleby glonów było mało, ponieważ wiosna, obfite deszcze przyczyniły się do zalania pola wodą na głębokość około $15 \mathrm{~cm}$. Glony z gleby przedostawały się do stagnującej wody, gdzie znajdowały nową przestrzeń dla swojego rozwoju. $Z$ powodu braku odpowiedniego sprzętu do poboru prób wody w momencie zbioru materiałów, biomasa glonów w wodzie nie została w oznaczona. Najmniej glonów rozwijało się w glebie systemu upraw konwencjonalnych. Próby pobierane były 4 tygodnie po drugim opryskiwaniu tej uprawy herbicydem Chwastox D (tab. 1).

Wraz ze zbiorem pszenicy pobierane były próby letnie. Temperatury, chociaż podobnie jak wiosną niższe w pierwszym roku badań (od czerwca do lipca suma temperatur niższa o $93,5^{\circ} \mathrm{C}$ ) i wyższe (o $30 \mathrm{~mm}$ ) niż w drugim roku opady, przyczyniły się jednak do osuszenia gleby i obniżenia biomasy glonów na powierzchni gleby średnio o około $0,10 \mathrm{~kg} / \mathrm{ha}$ i o $4 \mathrm{~kg} / \mathrm{ha} \mathrm{w}$ warstwie gleby do głębokości 0-30 cm, prawie jednakowo w systemie upraw ekologicznych i systemie integrowanym (rys. 3). Prawdopodobnie jednak, bardziej wilgotna gleba w systemie uprawy ekologicznej pozwalała na rozwój nieco większej ilości glonów niż w systemie integrowanym. Niemalże o połowę mniej glonów rozwijało się w obu warstwach gleby w systemie upraw konwencjonalnych (rys. 3, 4).

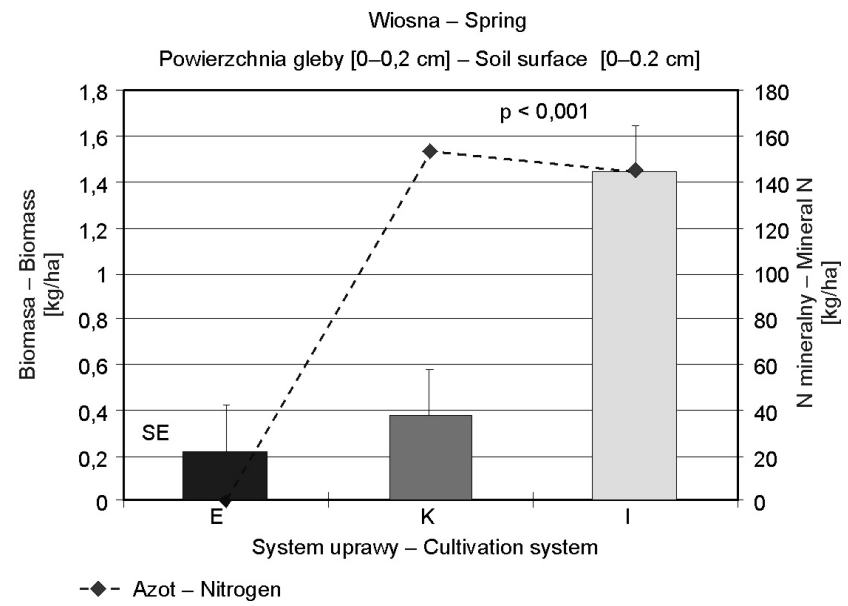

Rys. 1. Średnie stany biomasy glonów glebowych wiosna pierwszego roku badań na powierzchni gleby. E ekologiczny, K - konwencjonalny, I - integrowany system uprawy pszenicy ozimej, SE - błąd standardowy, $\mathrm{p}$ - poziom istotności

Fig. 1. Mean of soil algae biomass in spring of the first year of study on the soil surface. E - organic, $\mathrm{K}$ - conventional, I - integrated cultivation system of winter wheat, SE standard error, $p$ - significant level

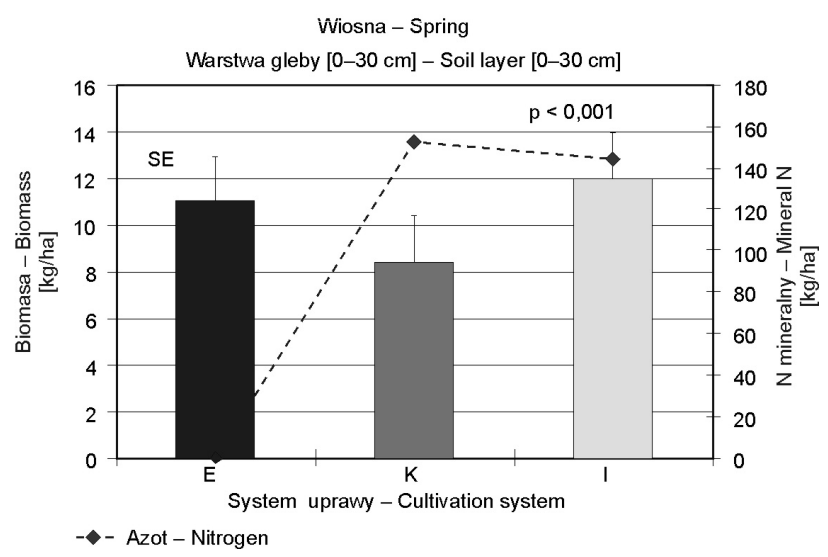

Rys. 2. Średnie stany biomasy glonów glebowych wiosną pierwszego roku badań $\mathrm{w}$ warstwie gleby do $30 \mathrm{~cm}$ głębokości. E - ekologiczny, K - konwencjonalny, I integrowany system uprawy pszenicy ozimej, SE - błąd standardowy, $\mathrm{p}$ - poziom istotności

Fig. 2. Mean of soil algae biomass in spring of the first year of study in the soil layer up to $30 \mathrm{~cm}$ of depth. E - organic, $\mathrm{K}$ - conventional, I - integrated cultivation system of winter wheat, SE - standard error, $\mathrm{p}$ - significant level 
Tabela 1. Zabiegi agrotechniczne zastosowane w uprawie pszenicy ozimej w pierwszym roku badań

Table 1. Agricultural practice applied to winter wheat cultivations in the first year of study

\begin{tabular}{|c|c|c|c|}
\hline \multicolumn{4}{|c|}{ System uprawy - Cultivation system } \\
\hline $\begin{array}{l}\text { Wyszcze- } \\
\text { gólnienie } \\
\text { Description }\end{array}$ & ekologiczny - organic & konwencjonalny - conventional & integrowany - integrated \\
\hline $\begin{array}{l}\text { Zmianowanie } \\
\text { Crop rotation }\end{array}$ & $\begin{array}{l}4 \text { lata rotacja (= wymiana pól) } \\
4 \text { years rotation (= field change) } \\
5 \text { lat zmianowanie } \\
\text { (= wymiana roślin na danym } \\
\text { polu) } \\
5 \text { years crop rotation } \\
\text { (= plant chance) } \\
\text { pszenica ozima + poplon: } \\
\text { winter wheat }+ \text { aftercrop: } \\
\text { I. bobik } 300 \mathrm{~kg} / \mathrm{ha}(06.08 .01) \\
\text { horse-been } 300 \mathrm{~kg} / \mathrm{ha}(06.08 .01) \\
\text { II. perko } 16 \mathrm{~kg} / \mathrm{ha}(08.08 .01) \\
\text { bird rape } 16 \mathrm{~kg} / \mathrm{ha}(08.08 .01) \\
\text { ziemniak }- \text { potato } \\
\text { jęczmień jary + koniczyna } \\
\text { spring barley + clover } \\
\text { koniczyna czerwona }-2 \text { lata } \\
\text { red clover }-2 \text { years }\end{array}$ & $\begin{array}{l}3 \text { lata } \\
3 \text { year rotation } \\
\\
\text { pszenica ozima - winter wheat } \\
\text { jęczmień jary - spring barley } \\
\text { rzepak ozimy - winter rape }\end{array}$ & $\begin{array}{l}4 \text { lata rotacja } \\
4 \text { years rotation } \\
5 \text { lat zmianowanie } \\
5 \text { years crop rotation } \\
\\
\text { pszenica ozima + poplon: } \\
\text { winter wheat }+ \text { aftercrop: } \\
\text { perko }+ \text { gorczyca biała } 5+15 \mathrm{~kg} / \mathrm{ha} \\
\text { bird rape }+ \text { white mustard } \\
5+15 \mathrm{~kg} / \mathrm{ha} \\
\text { ziemniak }- \text { potato } \\
\text { jęczmien jary }+ \text { koniczyna } \\
\text { spring barley }+ \text { clover } \\
\text { koniczyna czerw. (lub bobik) }-2 \text { lata } \\
\text { red clover (or horse-been) }-2 \text { years }\end{array}$ \\
\hline $\begin{array}{l}\text { Nawożenie } \\
\text { Fertilization }\end{array}$ & & 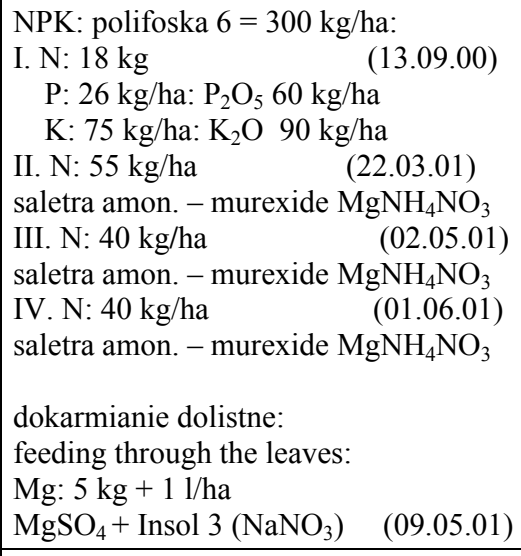 & 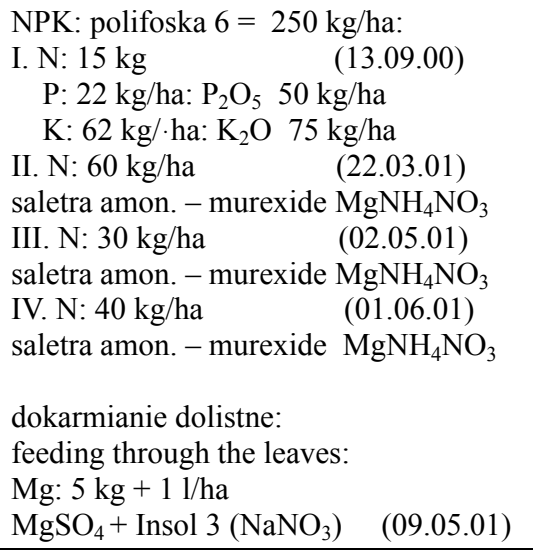 \\
\hline $\begin{array}{l}\text { Siew } \\
\text { Sowing }\end{array}$ & $\begin{array}{l}\text { pszenica ozima odmiana Elena } \\
\text { winter wheat variety Elena } \\
300 \mathrm{~kg} / \mathrm{ha} \\
\text { wrzesień - September }(23.09 .00)\end{array}$ & $\begin{array}{l}\text { pszenica ozima odmiana Elena } \\
\text { winter wheat variety Elena } \\
280 \mathrm{~kg} / \mathrm{ha} \\
+ \text { Baytan (fungicyd - fungicyde) } \\
\text { wrzesień - September } \quad(25.09 .00)\end{array}$ & $\begin{array}{l}\text { pszenica ozima odmiana Elena } \\
\text { winter wheat variety Elena } \\
280 \mathrm{~kg} / \mathrm{ha} \\
\text { wrzesień - September }\end{array}$ \\
\hline $\begin{array}{l}\text { Herbicydy } \\
\text { Herbicides }\end{array}$ & & \begin{tabular}{|l} 
I. Maraton 4,0 1/ha \\
październik - October \\
$\begin{array}{r}\text { (20.10.00) } \\
\text { II. Chwastox D 3,5 1/ha } \\
\text { kwiecień - April } \quad(30.04 .01)\end{array}$
\end{tabular} & $\begin{array}{l}\text { I. Maraton } 4,01 / \text { ha } \\
\quad \text { październik - October }(20.10 .00)\end{array}$ \\
\hline $\begin{array}{l}\text { Fungicydy } \\
\text { Fungicides }\end{array}$ & & 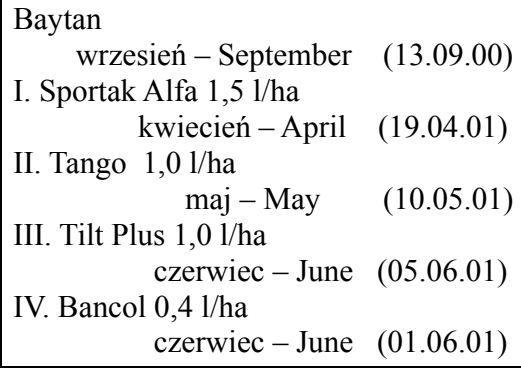 & 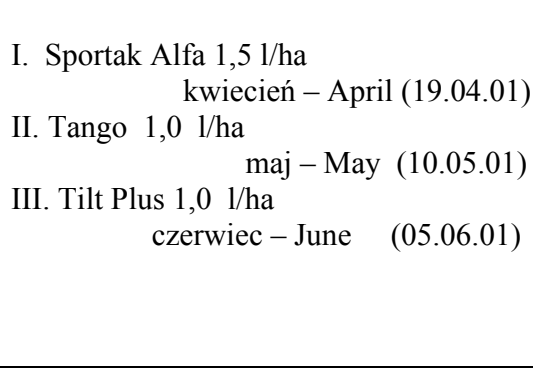 \\
\hline $\begin{array}{l}\text { Regulatory } \\
\text { wzrostu } \\
\text { Retardantes }\end{array}$ & & $\begin{array}{l}\text { I. Cycocel } 460 \text { SL 2,0 1/ha } \\
\text { kwiecień - April } \\
\begin{array}{r}\text { (30.04.01) } \\
\text { II. Terpal } 1,51 / \text { ha } \\
\text { maj-May } \quad(15.05 .01)\end{array}\end{array}$ & 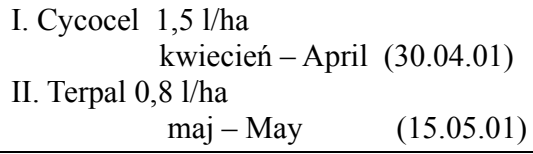 \\
\hline
\end{tabular}


Tabela 2. Zabiegi agrotechniczne zastosowane w uprawie przenicy ozimej w drugim roku badań

Table 2. Agricultural practice applied to winter whead cultivations in the secend year of study

\begin{tabular}{|c|c|c|c|}
\hline \multicolumn{4}{|c|}{ System uprawy - Cultivation system } \\
\hline $\begin{array}{l}\text { Wyszczegól- } \\
\text { nienie } \\
\text { Description }\end{array}$ & ekologiczny - organic & konwencjonalny - conventional & integrowany - integrated \\
\hline $\begin{array}{l}\text { Nawożenie } \\
\text { Fertilization }\end{array}$ & $\begin{array}{l}\text { obornik - manure } 30 \mathrm{t} / \mathrm{ha} \\
\text { październik - October }(25.10 .02) \\
\text { K: } 66 \mathrm{~kg} \text { Patent Kali }=100 \mathrm{~kg} \\
\mathrm{kwiecień}-\text { April }(03.04 .02) \\
\mathrm{Mg}: 10 \mathrm{~kg} \\
\mathrm{~S}: 35 \mathrm{~kg} \text { siarczan potasu }=100 \mathrm{~kg} \\
\text { sulphate potassium }=100 \mathrm{~kg} \\
\quad \text { kwiecień }- \text { April }(03.04 .02)\end{array}$ & 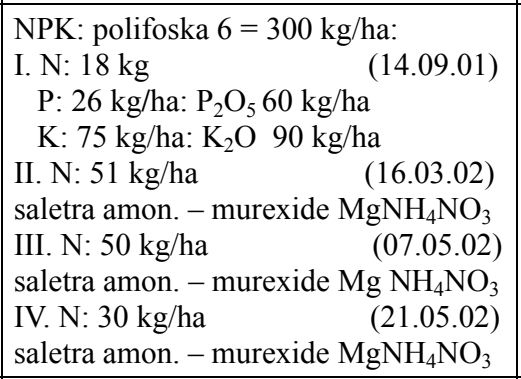 & $\begin{array}{l}\text { NPK: polifoska } 6=250 \mathrm{~kg} / \mathrm{ha}: \\
\text { I. N: } 15 \mathrm{~kg} \quad(14.09 .01) \\
\mathrm{P}: 22 \mathrm{~kg} / \mathrm{ha}: \mathrm{P}_{2} \mathrm{O}_{5} 50 \mathrm{~kg} / \mathrm{ha} \\
\mathrm{K}: 63 \mathrm{~kg} / \mathrm{ha}: \mathrm{K}_{2} \mathrm{O} 75 \mathrm{~kg} / \mathrm{ha} \\
\mathrm{II} . \mathrm{N}: 60 \mathrm{~kg} / \mathrm{ha} \quad(14.03 .02) \\
\text { saletra amon. }- \text { murexide } \mathrm{MgNH}_{4} \mathrm{NO}_{3} \\
\text { III. N: } 30 \mathrm{~kg} / \mathrm{ha} \quad(07.05 .02) \\
\text { saletra amon. }- \text { murexide } \mathrm{MgNH}_{4} \mathrm{NO}_{3} \\
\begin{array}{l}\text { IV. N: } 40 \mathrm{~kg} / \text { ha } \\
\text { saletra amon. }- \text { murexide } \mathrm{MgNH}_{4} \mathrm{NO}_{3}\end{array}\end{array}$ \\
\hline $\begin{array}{l}\text { Siew } \\
\text { Sowing }\end{array}$ & $\begin{array}{l}\text { pszenica ozima odmiana Elena } \\
\text { winter wheat variety Elena } \\
300 \mathrm{~kg} / \mathrm{ha} \\
\quad \text { wrzesień - September }(27.09 .01)\end{array}$ & \begin{tabular}{|l|} 
pszenica ozima odmiana Elena \\
winter wheat variety Elena \\
$\begin{array}{l}230 \mathrm{~kg} / \mathrm{ha} \\
\text { wrzesień - September }(27.09 .01)\end{array}$
\end{tabular} & $\begin{array}{l}\text { pszenica ozima odmiana Elena } \\
\text { winter wheat variety Elena } \\
250 \mathrm{~kg} / \mathrm{ha} \\
\quad \text { wrzesień - September }(26.09 .01)\end{array}$ \\
\hline $\begin{array}{l}\text { Herbicydy } \\
\text { Herbicides }\end{array}$ & & $\begin{array}{l}\text { I. Maraton } 4,01 / \text { ha } \\
\text { październik - October }(18.10 .01)\end{array}$ & $\begin{array}{r}\text { I. Maraton } 4,0 \mathrm{l} / \mathrm{ha} \\
\text { październik - October }(18.10 .01)\end{array}$ \\
\hline $\begin{array}{l}\text { Fungicydy } \\
\text { Fungicides }\end{array}$ & & \begin{tabular}{|c|}
$\begin{array}{r}\text { I. Bayleton Total } 1,0 \mathrm{~kg} \mathrm{ha} / 5001 \\
\text { kwiecień }- \text { April (30.04.02) }\end{array}$ \\
$\begin{array}{c}\text { II. Folikus Plus } 1,0 \mathrm{~kg} / \mathrm{ha} / 5001 \\
\text { maj }- \text { May } 21.05 .02)\end{array}$ \\
$\begin{array}{c}\text { III. Falkon } 1 \mathrm{~kg} / \mathrm{ha} / 5001 \\
\text { czerwiec }- \text { June } \quad(03.06 .02)\end{array}$ \\
\end{tabular} & $\begin{array}{l}\text { I. Bayleton Total } 0,8 \mathrm{~kg} / \mathrm{ha} / 3001 \\
\text { kwiecien }- \text { April }(30.04 .02) \\
\text { II. Falkon } 1 \mathrm{~kg} / \mathrm{ha} / 500 \mathrm{l} \\
\text { maj - April }(04.05 .02)\end{array}$ \\
\hline $\begin{array}{l}\text { Regulatory } \\
\text { wzrostu } \\
\text { Retardantes }\end{array}$ & & $\begin{array}{r}\text { I. Cycocel } 460 \text { SL 2,0 1/ha/500 l } \\
\text { maj - April } \quad(06.05 .02)\end{array}$ & $\begin{array}{r}\text { I. Cycocel } 1,5 \text { l/ha/400 l wody } \\
\text { maj - April (06.05.02) }\end{array}$ \\
\hline
\end{tabular}

Tabela 3. Warunki meteorologiczne

Table 3. Meteorological conditions

\begin{tabular}{|c|c|c|c|c|c|c|c|c|}
\hline \multicolumn{9}{|c|}{ Pierwszy rok badań - First year of investigation } \\
\hline $\begin{array}{l}\text { Miesiące } \\
\text { Month }\end{array}$ & $\begin{array}{l}\text { marzec } \\
\text { March }\end{array}$ & $\begin{array}{c}\text { kwiecień } \\
\text { April }\end{array}$ & $\begin{array}{l}\text { maj } \\
\text { May }\end{array}$ & $\begin{array}{l}\text { czerwiec } \\
\text { June }\end{array}$ & $\begin{array}{l}\text { lipiec } \\
\text { July }\end{array}$ & $\begin{array}{c}\text { sierpień } \\
\text { August }\end{array}$ & $\begin{array}{c}\text { wrzesień } \\
\text { September }\end{array}$ & $\begin{array}{c}\text { razem } \\
\text { total }\end{array}$ \\
\hline $\begin{array}{l}\text { Sumy temperatur } \\
\text { Sum of } \\
\text { temperature } \\
{\left[{ }^{\circ} \mathrm{C}\right]}\end{array}$ & 85,0 & 264,1 & 462,7 & 466,1 & 649,6 & 599,3 & 372,6 & 2899,4 \\
\hline $\begin{array}{l}\text { Sumy opadów } \\
\text { Sum of rainfall } \\
{[\mathrm{mm}]}\end{array}$ & 41,9 & 88,9 & 15,0 & 58,4 & 139,5 & 84,4 & 122,6 & 550,7 \\
\hline \multicolumn{9}{|c|}{ Drugi rok badań - Second year of investigation } \\
\hline $\begin{array}{l}\text { Sumy temperatur } \\
\text { Sum of } \\
\text { temperature } \\
{\left[{ }^{\circ} \mathrm{C}\right]}\end{array}$ & 143,8 & 267,0 & 546,2 & 540,7 & 668,5 & 636,6 & 395,0 & 3197,8 \\
\hline $\begin{array}{l}\text { Sumy opadów } \\
\text { Sum of rainfall } \\
{[\mathrm{mm}]}\end{array}$ & 39,7 & 13,0 & 10,1 & 88,4 & 78,8 & 26,3 & 34,5 & 290,8 \\
\hline
\end{tabular}


Lato - Summer

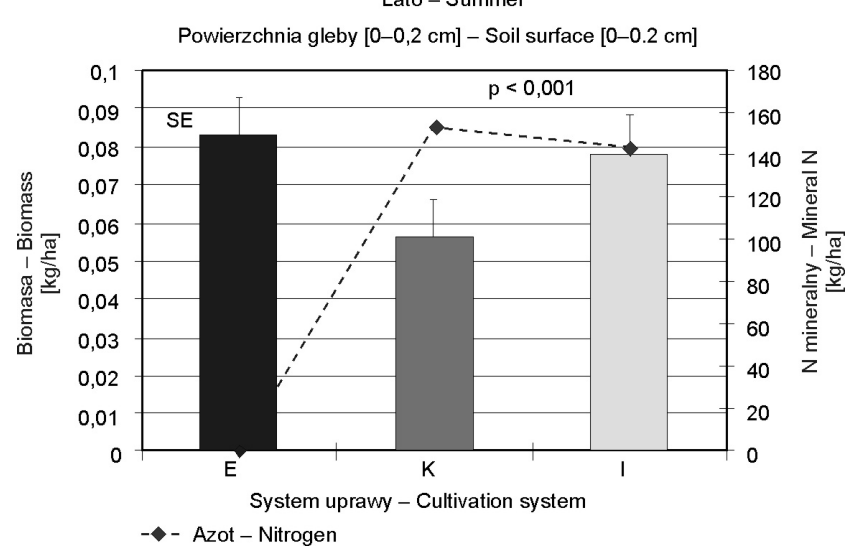

Rys. 3. Średnie stany biomasy glonów glebowych latem pierwszego roku badań na powierzchni gleby. E - ekologiczny, $\mathrm{K}$ - konwencjonalny, I - integrowany system uprawy pszenicy ozimej, SE - błąd standardowy, p - poziom istotności

Fig. 3. Mean of algal biomass in soil in summer of the first year of study on the soil surface. E - organic, K - conventional, I - integrated cultivation system of winter wheat, $\mathrm{SE}$ - standard error, $\mathrm{p}$ - significant level

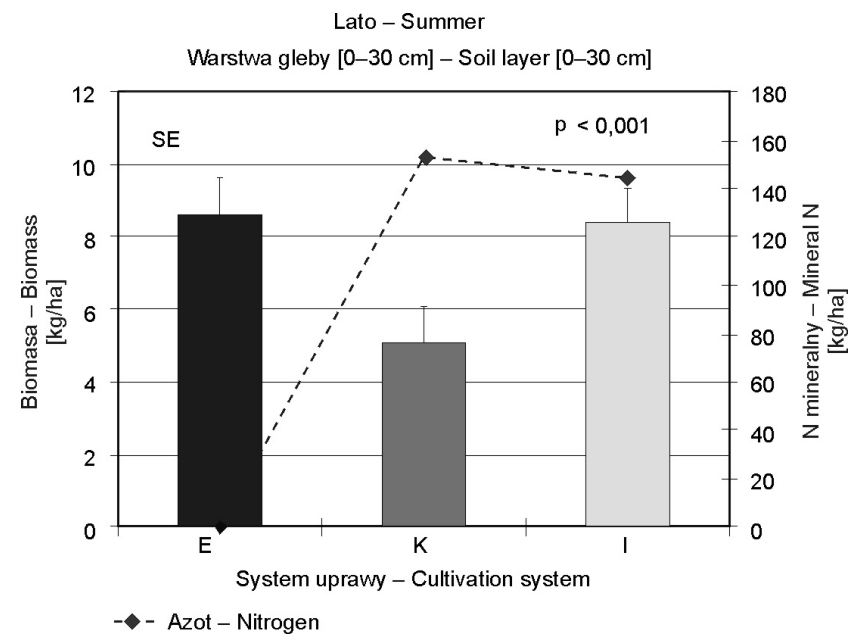

Rys. 4. Średnie stany biomasy glonów glebowych latem pierwszego roku badań w warstwie gleby do $30 \mathrm{~cm}$ głębokości. E - ekologiczny, K - konwencjonalny, I - integrowany system uprawy pszenicy ozimej, SE - błąd standardowy, $\mathrm{p}$ - poziom istotności

Fig. 4. Mean of algal biomass in soil in summer of the first year of study in the soil layer up to $30 \mathrm{~cm}$ of depth. E organic, K - conventional, I - integrated cultivation system of winter wheat, SE - standard error, $\mathrm{p}$ - significant level

Jesienne próby pobierane były na polach 2 miesiące po zbiorze pszenicy i wysiewie poplonu. Jak w poprzednich miesiącach pierwszego roku badań, suma temperatur (z sierpnia i września) była niższa o $58^{\circ} \mathrm{C}$ niż $\mathrm{w}$ drugim roku, natomiast opady $\mathrm{w}$ tym samym okresie były o $146 \mathrm{~mm}$ wyższe niż $\mathrm{w}$ drugim roku badań. Takie warunki meteorologiczne, mimo przeprowadzonej podorywki pozwoliły na odbudowę biomasy glonów na powierzchni gleby średnio o $0,048 \mathrm{~kg} / \mathrm{ha} w$ systemie upraw integrowanych (orka przyczynia się do zburzenia wytwo- rzonych zbiorowisk glonów i przez to obniżenia biomasy glonów glebowych) (Sieminiak 1997, 1998). Podobnie, jak latem, o prawie połowę mniej glonów było w systemie konwencjonalnym, a tylko $1 / 3$ z masy glonów z systemu upraw integrowanych rozwijała się $\mathrm{w}$ glebie systemu upraw ekologicznych (rys. 5). Najniższa biomasa glonów na powierzchni gleby $w$ systemie upraw ekologicznych była prawdopodobnie spowodowana najintensywniej przebiegającym procesem wymywania glonów przez deszcze z powierzchni w głębsze warstwy gleby. Podobne zjawisko opisywał Lund (1945) oraz Sztna i Gollerbach (1976).

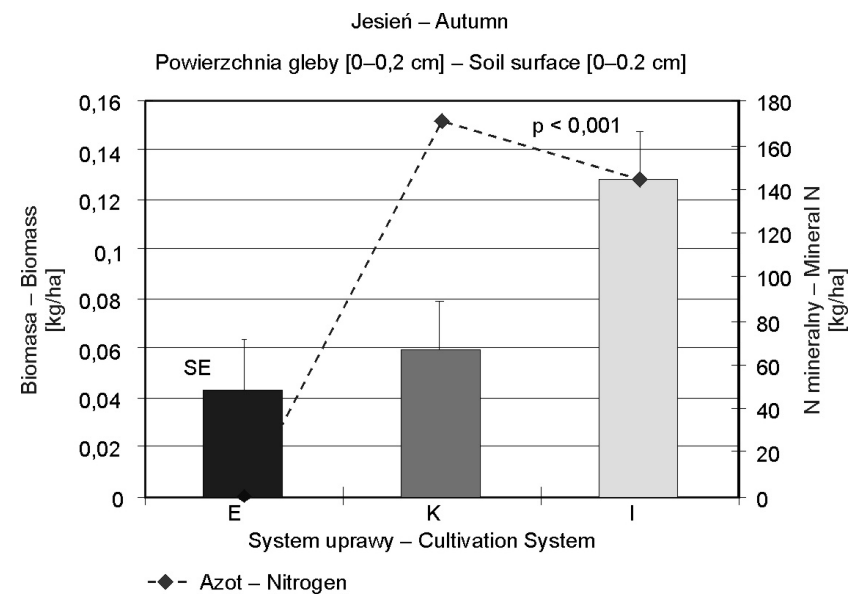

Rys. 5. Średnie stany biomasy glonów glebowych jesienią pierwszego roku badań na powierzchni gleby. E ekologiczny, K - konwencjonalny, I - integrowany system uprawy pszenicy ozimej, SE - błąd standardowy, $\mathrm{p}$ - poziom istotności

Fig. 5. Mean of soil algae biomass in autumn of the first year of study on the soil surface. E - organic, K - conventional, I - integrated cultivation system of winter wheat, SE standard error, $\mathrm{p}$ - significant level

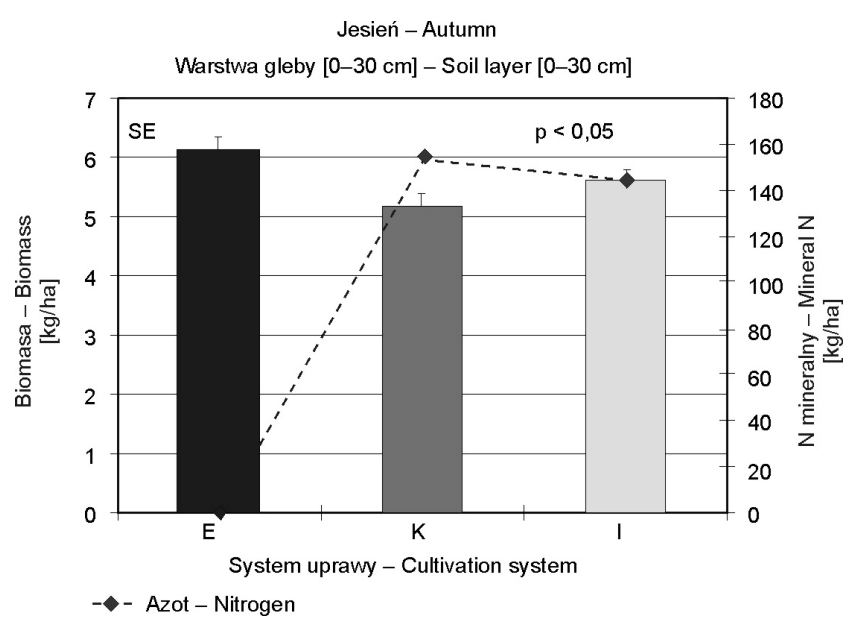

Rys. 6. Średnie stany biomasy glonów glebowych jesienią pierwszego roku badań $\mathrm{w}$ warstwie gleby do $30 \mathrm{~cm}$ głębokości. E - ekologiczny, K - konwencjonalny, I integrowany system uprawy pszenicy ozimej, SE - błąd standardowy, $\mathrm{p}$ - poziom istotności

Fig. 6. Mean of soil algae biomass in autumn of the first year of study in the soil layer up to $30 \mathrm{~cm}$ of depth. E - organic, $\mathrm{K}$ - conventional, I - integrated cultivation system of winter wheat, $\mathrm{SE}$ - standard error, $\mathrm{p}$ - significant level 
Znaczna ilość opadów (224 mm w ciagu dwóch miesięcy: sierpień i wrzesień) sprzyjała większemu, niż w pozostałych uprawach uwilgoceniu skłonnej do podtopień gleby i rozwinięciu największej w tym okresie średniej biomasy glonów w systemie upraw ekologicznych, która jednakże (prawdopodobnie ze względu na równocześnie zachodzący proces wmywania glonów w głębsze warstwy gleby) była niższa o $2 \mathrm{~kg} / \mathrm{ha}$ od najwyższej średniej biomasy glonów w okresie zbioru pszenicy i o $5 \mathrm{~kg} / \mathrm{ha}$ niższa od najwyższej średniej biomasy glonów wiosną. Prawie dorównuje jej wielkością średnia biomasa glonów w systemie uprawy integrowanej, a niewiele niższa od nich była średnia biomasa glonów w systemie uprawy konwencjonalnej (rys. 6).

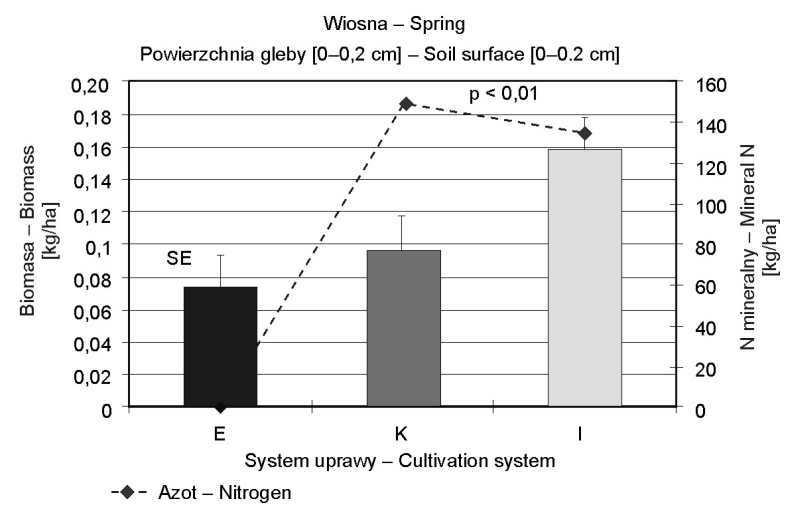

Rys. 7. Średnie stany biomasy glonów glebowych wiosną drugiego roku badań na powierzchni gleby. E - ekologiczny, $\mathrm{K}$ - konwencjonalny, I - integrowany system uprawy pszenicy ozimej, SE - błąd standardowy, p - poziom istotności

Fig. 7. Mean of soil algae biomass in spring of the second year of study on the soil surface. E - organic, $\mathrm{K}$ - conventional, I - integrated cultivation system of winter wheat, $\mathrm{SE}$ - standard error, $\mathrm{p}$ - significant level

Wiosna - Spring

Warstwa gleby $[0-30 \mathrm{~cm}]$ - Soil layer $[0-30 \mathrm{~cm}]$

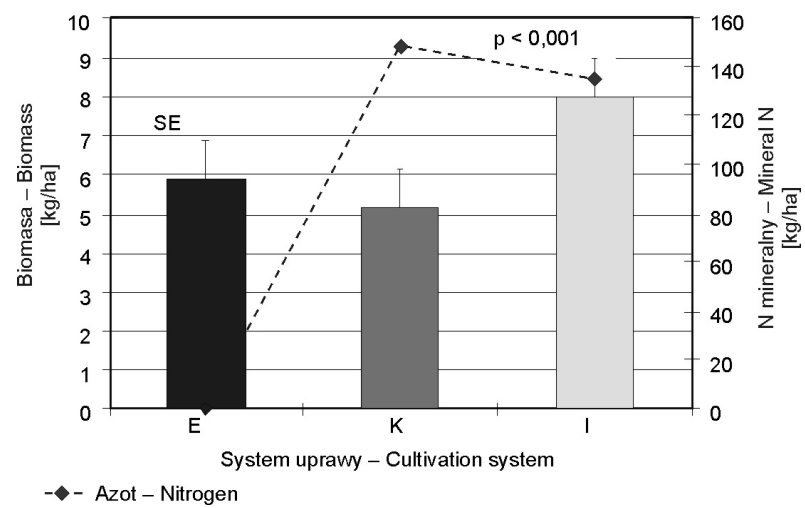

Rys. 8. Średnie stany biomasy glonów glebowych wiosną drugiego roku badań w warstwie gleby do $30 \mathrm{~cm}$ głębokości. $\mathrm{E}$ - ekologiczny, $\mathrm{K}$ - konwencjonalny, I - integrowany system uprawy pszenicy ozimej, SE - błąd standardowy, $\mathrm{p}$ - poziom istotności

Fig. 8. Mean of soil algae biomass in spring of the second year of study in the soil layer up to $30 \mathrm{~cm}$ of depth. E organic, $\mathrm{K}$ - conventional, I - integrated cultivation system of winter wheat, SE - standard error, $p$ - significant level

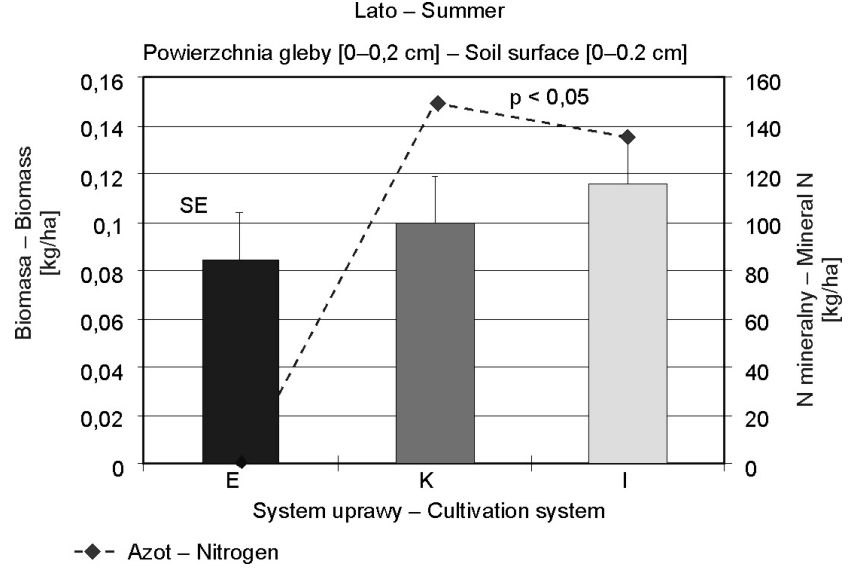

Rys. 9. Średnie stany biomasy glonów glebowych latem drugiego roku badań na powierzchni gleby. E - ekologiczny, $\mathrm{K}$ - konwencjonalny, I - integrowany system uprawy pszenicy ozimej, SE - błąd standardowy, p - poziom istotności

Fig. 9. Mean of soil algae biomass in summer of the second year of study on the soil surface. E - organic, $\mathrm{K}$ - conventional, I - integrated cultivation system of winter wheat, $\mathrm{SE}$ - standard error, $\mathrm{p}$ - significant level

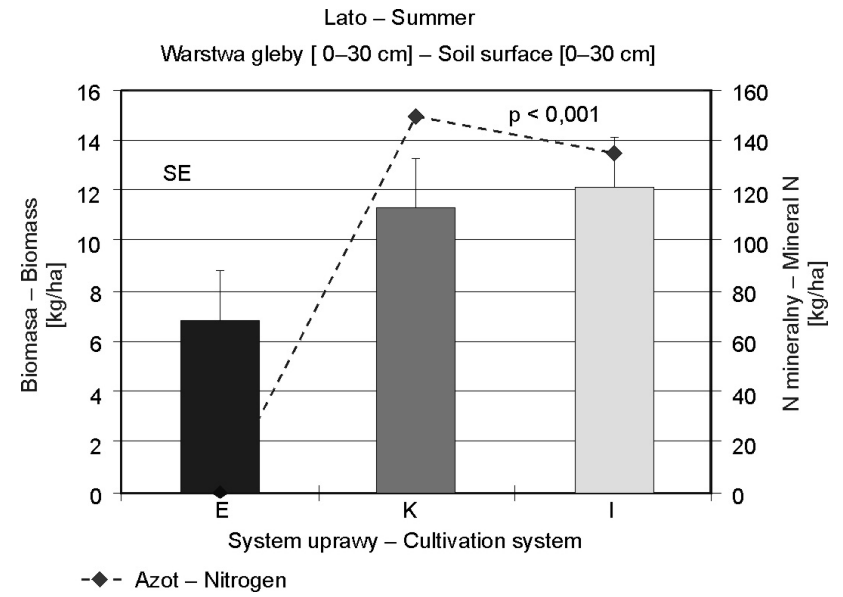

Rys. 10. Średnie stany biomasy glonów glebowych latem drugiego roku badań w warstwie gleby do $30 \mathrm{~cm}$ głębokości. E - ekologiczny, K - konwencjonalny, I integrowany system uprawy pszenicy ozimej, SE błąd standardowy, $\mathrm{p}$ - poziom istotności

Fig. 10. Mean of soil algae biomass in summer of the second year of study in the soil layer up to $30 \mathrm{~cm}$ of depth. $\mathrm{E}$ - organic, $\mathrm{K}$ - conventional, I - integrated cultivation system of winter wheat, SE - standard error, $\mathrm{p}-$ significant level

Drugi rok badań charakteryzują wiosną (marzec-maj) niższe niż w poprzednim roku opady (tylko $60 \mathrm{~mm}$ ) i wyższe temperatury. Glonów na powierzchni gleby we wszystkich uprawach było mniej niż w okresie wiosennym poprzedniego roku. Największa średnia biomasa glonów na powierzchni gleby stwierdzona została w systemie integrowanej uprawy pszenicy, a najniższa w systemie uprawy ekologicznej (rys. 7). Również w warstwie gleby do $30 \mathrm{~cm}$ najwięcej glonów rozwijało się w systemie uprawy integrowanej, mniej w systemie ekologicznym, 


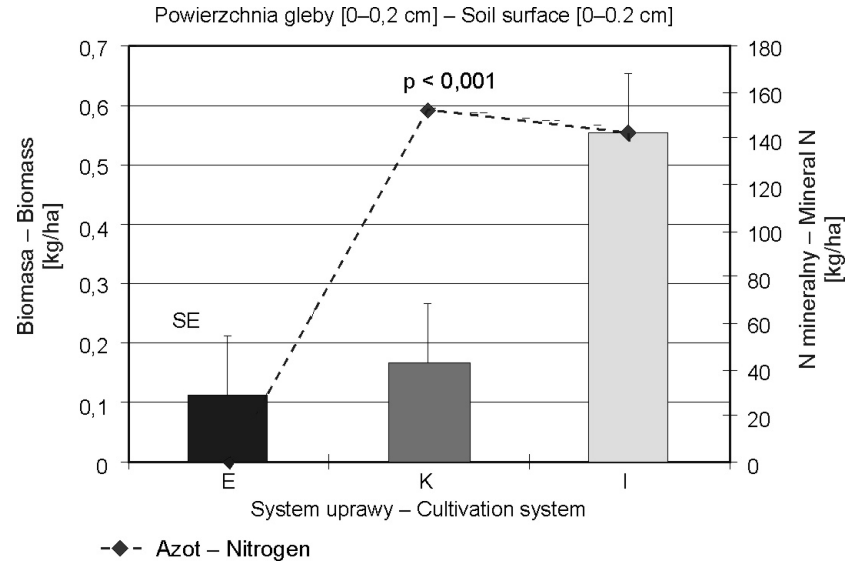

Rys. 11. Średnia biomasa glonów glebowych w pierwszym roku badań na powierzchni gleby. E - ekologiczny, $\mathrm{K}$ - konwencjonalny, I - integrowany system uprawy pszenicy ozimej, SE - błąd standardowy, p - poziom istotności

Fig. 11. Mean of soil algae biomass in the first year of study on the soil surface. E - organic, K - conventional, I - integrated cultivation system of winter wheat, SE standard error, $\mathrm{p}$ - significant level

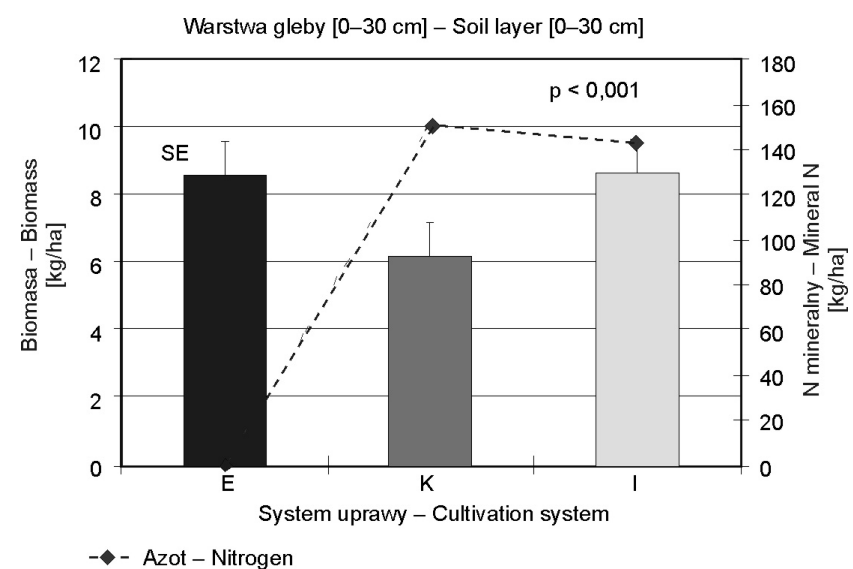

Rys. 12. Średnia biomasa glonów glebowych w pierwszym roku badań w warstwie gleby do $30 \mathrm{~cm}$ głębokości. E - ekologiczny, K - konwencjonalny, I - integrowany system uprawy pszenicy ozimej, SE - błąd standardowy, $\mathrm{p}$ - poziom istotności

Fig. 12. Mean of soil algae biomass in the first year of study in the soil layer up to $30 \mathrm{~cm}$ of depth. E - organic, $\mathrm{K}$ - conventional, I - integrated cultivation system of winter wheat, $\mathrm{SE}$ - standard error, $\mathrm{p}$ - significant level

a w odróżnieniu od warstwy powierzchniowej, najmniej, jak zawsze do tego czasu w systemie uprawy konwencjonalnej (rys. 8). Wobec braku zastosowania wiosną drugiego herbicydu w systemie konwencjonalnym, w stosunku do roku ubiegłego, nie stwierdzono istotnych różnic w proporcjach biomasy glonów w poszczególnych systemach uprawy pszenicy (rys. 1, 2, 7, 8).

W miesiącach letnich (czerwiec, lipiec) zarówno na powierzchni gleby (rys. 9), jak i w warstwie do $30 \mathrm{~cm}$ (rys. 10), glonów było więcej niż latem poprzedniego roku. Wyższe temperatury i o $30 \mathrm{~mm}$ mniejsze niż w roku poprzednim opady zatrzymały proces wmywania komórek w głąb gleby. Średnia biomasa glonów na powierzchni gleby była przeważnie wyższa niż wiosną (oprócz powierzchni gleby w systemie upraw integrowanych) i podobnie jak wiosna, największa była $\mathrm{w}$ integrowanym, a najmniejsza w ekologicznym systemie uprawy. W odróżnieniu od wiosny, jak również od całego roku poprzedniego, w warstwie gleby do $30 \mathrm{~cm}$, biomasa glonów kształtowała się podobnie, jak na powierzchni gleby największe jej wartości oznaczone zostały w integrowanym, a najmniejsze w ekologicznym systemie uprawy. $\mathrm{W}$ następstwie rezygnacji z zastosowania wiosną drugiego zabiegu herbicydem, średni stan biomasy w konwencjonalnym systemie uprawy wyraźnie zbliżył się do biomasy glonów w systemie integrowanym.

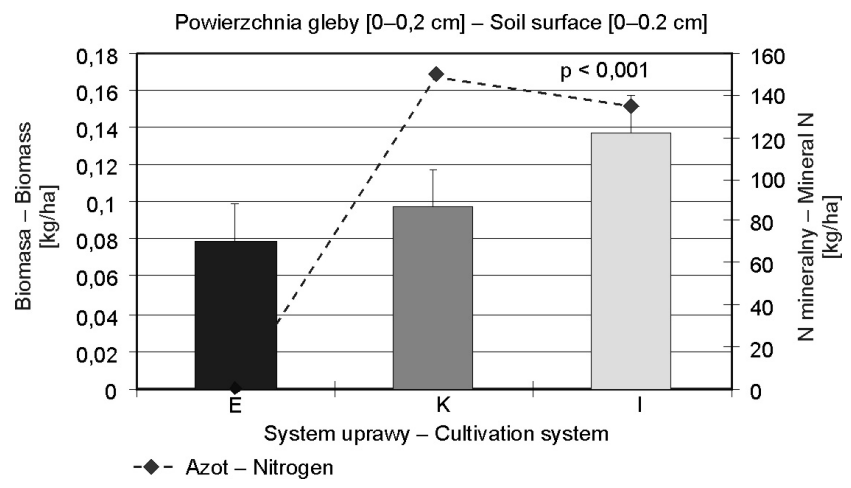

Rys. 13. Średnia biomasa glonów glebowych w drugim roku badań na powierzchni gleby. E - ekologiczny, $\mathrm{K}$ - konwencjonalny, I - integrowany system uprawy pszenicy ozimej, SE - błąd standardowy, p - poziom istotności

Fig. 13. Mean of soil algae biomass in the second year of study on the soil surface. E - organic, K - conventional, I - integrated cultivation system of winter wheat, SE standard error, $\mathrm{p}$ - significant level

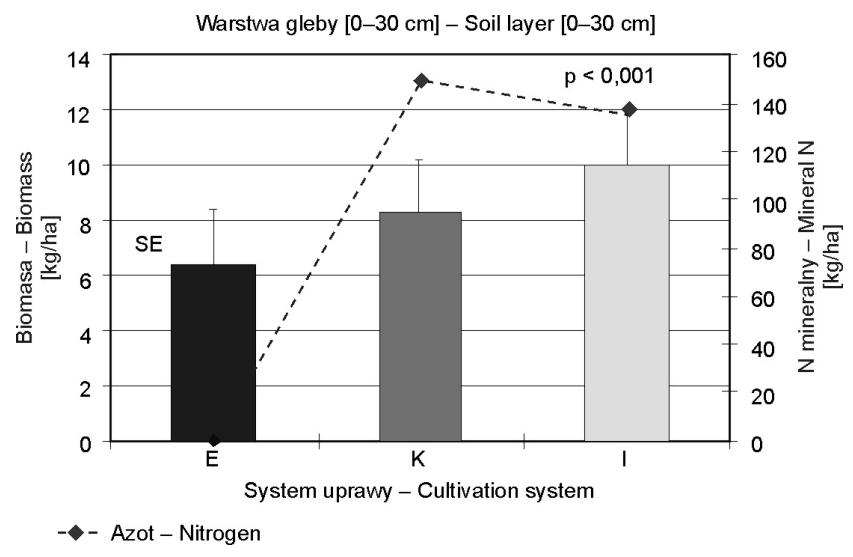

Rys. 14. Średnia biomasa glonów glebowych w drugim roku badań $\mathrm{w}$ warstwie gleby do $30 \mathrm{~cm}$ głębokości. E ekologiczny, K - konwencjonalny, I - integrowany system uprawy pszenicy ozimej, SE - błąd standardowy, $\mathrm{p}$ - poziom istotności

Fig. 14. Mean of soil algae biomass in the second year of study in the soil layer up to $30 \mathrm{~cm}$ of depth. E - organic, $\mathrm{K}-$ conventional, I - integrated cultivation system of winter wheat, SE - standard error, $p$ - significant level 


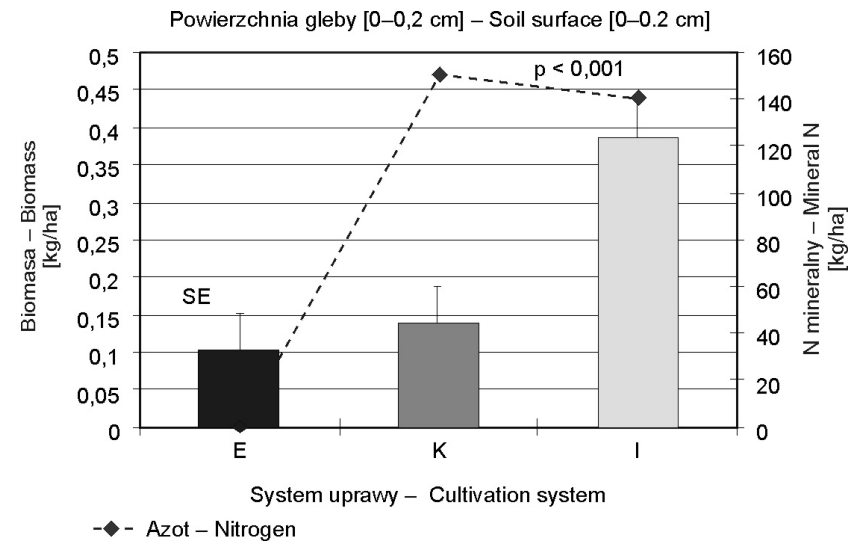

Rys. 15. Średnia biomasa glonów glebowych na powierzchni gleby i w warstwie gleby do $30 \mathrm{~cm}$ głębokości dla obu lat badań łącznie. E - ekologiczny, K - konwencjonalny, I - integrowany system uprawy pszenicy ozimej, SE - błąd standardowy, $\mathrm{p}$ - poziom istotności

Fig. 15. Mean of soil algae biomass for both years of study on the soil surface and in the soil layer up to $30 \mathrm{~cm}$ of depth. E - organic, K - conventional, I - integrated cultivation system of winter wheat, $\mathrm{SE}$ - standard error, $\mathrm{p}$ - significant level

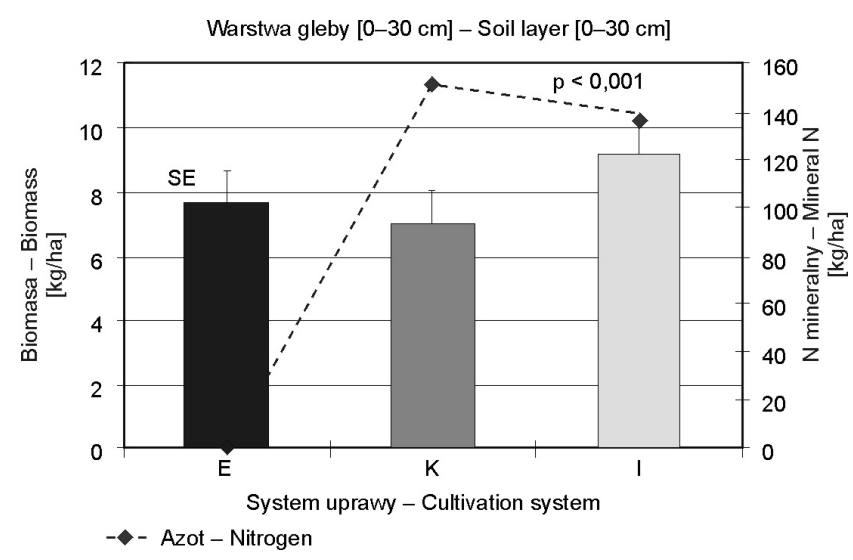

Rys. 16. Średnia biomasa glonów glebowych w warstwie gleby do $30 \mathrm{~cm}$ głębokości dla obu lat badań łącznie. E - ekologiczny, K - konwencjonalny, I - integrowany system uprawy pszenicy ozimej, SE - błąd standardowy, $\mathrm{p}$ - poziom istotności

Fig. 16. Mean of soil algae biomass for both years of study in the soil layer up to $30 \mathrm{~cm}$ of depth. E - organic, $\mathrm{K}$ - conventional, I - integrated cultivation system of winter wheat, $\mathrm{SE}$ - standard error, $\mathrm{p}$ - significant level

Analiza wszystkich wyników $\mathrm{z}$ poszczególnych lat badań dla każdego $\mathrm{z}$ poletek $\mathrm{z}$ pszenicą $\mathrm{w}$ wybranych systemach uprawy wykazała istotne różnice (na poziomie $\mathrm{p}<0,001)$ w wielkości biomasy glonów glebowych oddzielnie w każdym roku badań i w obu latach badań traktowanych łącznie (rys. 11-16). W pierwszym roku badań na powierzchni gleby najwięcej glonów rozwijało się w integrowanym systemie uprawy (rys. 11). W warstwie gleby do głębokości $30 \mathrm{~cm}$ biomasa glonów rozwijających się $\mathrm{w}$ glebie systemu integrowanego prawie dorównywała biomasie glonów w systemie ekologicznym (rys. 12). Zarówno najniższa średnia biomasa glonów na powierzchni gleby w ekologicznym systemie uprawy, jak i jej wielkość dorównująca biomasie w systemie uprawy integrowanej w warstwie gleby do $30 \mathrm{~cm}$, wiązały się po części z usytuowaniem pola (podtapianie przy dużych opadach).

Podobnie w drugim roku badań, najwyższe wartości biomasy glonów stwierdzone zostały w integrowanym systemie uprawy zarówno na powierzchni gleby, jak i w warstwie do $30 \mathrm{~cm}$. W odróżnieniu od poprzedniego roku, więcej glonów niż w systemie ekologicznym rozwijało się w konwencjonalnym systemie uprawy. $\mathrm{Na}$ powierzchni gleby ich biomasa zbliżała się bardziej do wielkości biomasy glonów w ekologicznym systemie uprawy (rys. 13), ale w warstwie gleby do głębokości $30 \mathrm{~cm}$ była bliższa wielkości biomasy w systemie integrowanym (rys. 14). Zwiększenie, w stosunku do roku poprzedniego, udziału glonów w konwencjonalnym systemie uprawy nastąpiło po rezygnacji z zastosowania wiosennego opryskiwania drugim herbicydem.

Analiza wyników z obu lat łącznie wskazuje, że biomasa glonów w integrowanym systemie uprawy nie tylko na powierzchni gleby (jak wynikało niekiedy z analiz dla poszczególnych sezonów czy pierwszego roku badań), ale i w warstwie gleby do głębokości $30 \mathrm{~cm}$ istotnie $(\mathrm{p}<0,001)$ przewyższa biomasę glonów w glebie pozostałych systemów uprawy (rys. 15, 16). Wynik przeprowadzonych badań jest zgodny $\mathrm{z}$ dotychczasową wiedzą o procesach fizjologicznych zachodzących u glonów glebowych. Tworzenie biomasy glonów o większych niż w innych systemach uprawy rozmiarach zachodziło w integrowanym systemie uprawy pszenicy mimo stosowania niższego niż $w$ systemie konwencjonalnym nawożenia mineralnego i mimo, że glony glebowe jako czułe wskaźniki zasobów mineralnych gleby wykorzystują do swojego rozwoju wszystkie nadwyżki substancji mineralnych w środowisku (Stokes 1940; Fuller i Roger 1952; Pipe i Schubert 1984; Sztina 1990). Przyczyną obniżenia biomasy glonów w systemie konwencjonalnym było zastosowanie drugiego zabiegu herbicydem Chwastox D, który uważany jest za bezpieczny dla środowiska, ponieważ zwalcza chwasty w oparciu o naturalne związki chemiczne (Paradowski 2013). Wykazane w niniejszej pracy szkodliwe oddziaływanie substancji czynnych tego herbicydu na glony glebowe może mogłoby ulec obniżeniu dzięki zastosowaniu o połowę niższych dawek herbicydu, które by równie skutecznie, jak dawki zalecane oddziaływały na chwasty (Haliniarz i Kapeluszny 2010). W ekologicznym systemie uprawy pszenicy, chociaż chronionym przed pestycydami, ale pozbawionym bezpośredniego dopływu mineralnych form fosforu i azotu, których pojaw wywołuje błyskawiczną reakcję glonów, biomasa glonów glebowych była niższa.

\section{Wnioski / Conclusions}

1. Średnie stany biomasy glonów w poszczególnych systemach w sezonach pierwszego i drugiego roku badań różniły się istotnie statystycznie.

2. W sezonach (w 5 terminach pobierania prób), największa biomasa glonów na powierzchni gleby rozwijała się w uprawie integrowanej. Tylko jeden raz była 
nieznacznie niższa niż średnia biomasa glonów w uprawie ekologicznej. Podobnie w warstwie gleby do $30 \mathrm{~cm}$ głębokości. Tylko dwa razy w pierwszym roku badań (latem i jesienią), w okresie obfitującym w deszcze najwyższe wartości biomasy glonów stwierdzone zostały w uprawie ekologicznej (możliwy wpływ warunków abiotycznych).
3. Brak zastosowania drugiego herbicydu w uprawie konwencjonalnej przyczynił się do istotnego wzrostu biomasy glonów w obu warstwach gleby.

4. Łączne oceny wszystkich wyników badań wskazują, że najwyższe wartości biomasy glonów glebowych stwierdzone zostały w uprawie integrowanej. W warstwie gleby do $30 \mathrm{~cm}$ głębokości, do rozmiarów biomasy glonów w uprawie integrowanej zbliżały się wartości biomasy glonów w uprawie ekologicznej.

\section{Literatura / References}

Fuller W.H., Rogers R.N. 1952. Utilization of the phosphorus of algal cells as measured by the Neubayer technique. Soil Sci. 74 (6): $417-430$.

Gollerbach M.M., Shtina E.A. 1969. Pochviennyje vodorosli. Nauka, Leningrad, 228 pp.

Jończyk K. 2005. Ocena wykorzystania i strat azotu w ekologicznym i konwencjonalnym systemie produkcji roślinnej. s. 77-83. W: „Wybrane zagadnienia ekologiczne we współczesnym rolnictwie” (Z. Zbytek, red.). PIMR, Poznań, Monografia, T. 2, cz. 1, 375 ss.

Haliniarz M., Kapeluszny J. 2010. Wpływ obniżonej dawki herbicydu MCPA + mekoprop + dikamba na zachwaszczenie trzech odmian pszenicy jarej. [The influence of reduced herbicide dose MCPA + mecoprop + dicamba on weed infestation of three varieties of spring wheat]. Prog. Plant Prot./Post. Ochr. Roślin 50 (2): 798-801.

Kuś J. 1998. Wstępne porównanie trzech systemów produkcji roślinnej (konwencjonalny, integrowany i ekologiczny). Rocz. AR Poznań 307, Rol. 52 (2): 119-126.

Kuś J. 2005. Plonowanie roślin w systemie ekologicznym, integrowanym i konwencjonalnym. s. 37- 46. W: „Wybrane zagadnienia ekologiczne we współczesnym rolnictwie” (Z. Zbytek, red.). PIMR, Poznań, Monografia, T. 2, cz. 1, 375 ss.

Lund J.W.G. 1945. Observation on soil algae. I. The ecology, size and taxonomy of British soil diatoms. New Phytologist 44 (2): 196-219.

Paradowski A. 2013. MCPA i MCPP-P działanie i wykorzystanie w rolnictwie. http://www.farmer.pl/produkcja-roslinna/ochronaroslin/mcpa-i-mcpp-p-dzialanie-i-wykorzystanie-w-rolnictwie,43216.html [dostęp: 07.10.2013].

Pipe A.E., Schubert L.E. 1984. The use of ALgae as indicators of soil fertility. p. 213-233. In: "Algae as Ecological Indicators" (L.E. Shubert, ed.). Academic Press, INC. London, Orlando, San Diego, New York, Austin, Boston, Sydney, Tokyo, Toronto, 434 pp.

Sieminiak D. 1996. Evaluation of algal biomass in the soil of a barren land. Ekol. Polska 44 (1): 225-246.

Sieminiak D. 1997. Biomasa glonów w glebie terenów krajobrazu rolniczego. Rocz. AR Poznań 294, Melior. Inż. Środ. 19 (1): $47-54$.

Sieminiak D. 1998. Biomass of soil algae under rye in different crop rotation system. Pol. J. Soil Sci. 31 (2): $79-85$.

Sieminiak D. 2003. Soil algae in two farming systems of potato cropping. Bull. Pol. Acad. Sci. 51 (1): 1-8.

Stokes J.L. 1940. The influence of environmental factors upon the development of algae and other mikroorganisms in the soil. Soil Sci. 49: $265-275$.

Sztina E.A., Gollerbach M.M. 1976. Ekologija pochvennych vodoroslej. Nauka, Moskva, 144 pp.

Sztina E.A. 1990. Soil algae as ecological indicators. Botanicheskii Zhurnal 75 (4): 441-453.

Thomas L., Schubert E., Trainor F.R. 1981. Ecology of soil algae: a review. Phycologia 20: 65-81.

Treubox O. 1905. Organische Sauren als Kohlenstoffquellebei algen. Ber. Deutsch. Bot. Ges. 23, p. 432. 